\title{
Public Policy Towards the Sale of State Assets in Troubled Times: Lessons from the Irish Experience*
}

\author{
Paul K Gorecki, ${ }^{a}$ Sean Lyons ${ }^{a}$ and Richard S. J. Tol ${ }^{a, b}$
}

\begin{abstract}
Governments throughout the western world and beyond are in the midst of a severe financial crisis and emerging from a sharp recession. Ireland is no exception. One of the options for strengthening public finances is the sale of state assets. In this paper we draw on the Irish experience to inform the wider debate on this important issue. Debate over the potential saleability of certain tangible and intangible assets owned by the state turns into much more than an exercise in ranking these assets by commercial viability and value. Careful attention needs to be devoted to ensuring that wider public policy considerations are taken into account, such competition, regulation and economic development. Hence it is important to formulate terms of reference for any consideration of the sale of state assets that reflect these wider concerns. In the case of tangible assets - commercial state firms - the debate is around whether these firms should be the public sector and whether the objectives can be better met by alternative arrangements. In privatising these state-owned firms careful attention needs to be paid to ensure that markets are well organised and competitive. This may necessitate for example breaking up a vertically integrated firm into its competitive and monopoly parts. To a considerable degree the debate over privatisation reflects issues related to the regulatory reform agenda. But in both cases what is on offer is a more efficient and competitive economy if reform is conducted sensibly and is not derailed by vested interests as has been the case, on occasion, in the past. In terms of intangible assets such as permits of various kinds such a those relating to carbon, wind turbine and oil exploration as well as radio spectrum licences, the conclusion is much more straightforward: these assets should be auctioned off to the highest bidder, but using a carefully designed auction which needs to take into account the competitive situation amongst the bidders not only to prevent collusion and gaming, but also to encourage entry and competition. Another important reason to auction these assets is that there is a danger, absent auctioning, that government will be unaware that these are valuable assets and hence not properly price them when making public policy decisions.
\end{abstract}

Keywords: privatisation; regulation; competition; tangible assets; intangible assets; Ireland; intangible state assets; tangible state assets.

\section{Corresponding author: paul.gorecki@esri.ie}

\footnotetext{
* We should like to thank Ron Hirshhorn and John Fitz Gerald for helpful comments. An earlier version of this paper was submitted to the Review Group of State Assets and Liabilities, details of which are contained in the text. The usual disclaimer applies.

a. Economic and Social Research Institute, Dublin and Department of Economics, Trinity College Dublin.

b. Institute for Environmental Economics, Vrije Universiteit, Amsterdam \& Department of Spatial Economics, Vrije Universiteit, Amsterdam.
}

ESRI working papers represent un-refereed work-in-progress by researchers who are solely responsible for the content and any views expressed therein. Any comments on these papers will be welcome and should be sent to the author(s) by email. Papers may be downloaded for personal use only. 


\section{Public Policy Towards the Sale of State Assets in Troubled Times: Lessons from the Irish Experience}

\section{Introduction}

Governments throughout the western world and beyond are in the midst of a severe financial crisis and emerging from a sharp recession. Ireland is no exception, indeed its banking crisis and economic performance are amongst the worst. Eliminating the structural deficit - by some estimates 5-7\% of Irish GDP, through a judicious combination of expenditure reductions and tax increases is vital to ensuring sound public finances. As part of this process Ireland is considering privatising some of the tangible and intangible assets that the state owns. The Review Group of State Assets and Liabilities was established in July 2010 by the Minister of Finance "to examine and provide advice on the proper stewardship of state assets and on opportunities for better use of those assets."

The sale of state assets is likely to be an option considered not only by the Irish government but also by other national governments. However, prior to any decision to sell state assets careful consideration needs to be given to wider issues than maximising revenue from asset sales. State-owned assets in Ireland and other countries are frequently of considerable economic and strategic importance. The commercial state-owned firms in Ireland, for example, control the major airports, urban and, to a lesser extent, inter-urban bus travel, ports, railways, electricity generation, transmission, and distribution, gas distribution and supply, postal services, TV and radio broadcasting, forestry and solid fuel production. In terms of intangible assets, the State creates and is responsible for allocating radio spectrum for broadcasting and telecommunications, mineral, hydrocarbon and other licences, and carbon dioxide emission permits. ${ }^{2}$ Furthermore, the State and organisations close to the State provide a wide range of services, some of which primarily serve private

\footnotetext{
${ }^{1}$ Taken from Department of Finance website: http://www.finance.gov.ie/viewdoc.asp?DocID=6396. Accessed 29 July 2010.

${ }^{2}$ An interim list of assets to be reviewed by the Group includes 28 commercial state bodies and three classes or types of intangible assets. For details see source in previous footnote. Aer Lingus is not listed, but it is obviously a state-owned asset whose value could be quickly realised. In other jurisdictions, such as England, water utilities are privately-owned commercial firms, but publicly regulated. Hence there is an argument for inclusion of both Aer Lingus and water utilities in the assets reviewed by the Group.
} 
interests. The brand and expertise of such bodies should be seen as intangible assets too.

The purpose of this paper is to discuss what factors should be taken into account, what questions should be asked, in deciding which state assets should be sold, the regulatory and other mechanisms that might be introduced to complement such asset sales, and some of the difficulties that are likely to be experienced in conducting assets sales. Although the focus of the paper is on the Irish experience, the lessons have, we believe, wider applicability.

In Section 2 of the paper the terms of reference that might be given to a task force or departmental committee set up to consider which assets should be privatised are considered. Attention then turns to the types of factors that need to be taken into account in the selection for sale of tangible assets (Section 3), before attention turns to intangible assets in Section 4. A conclusion completes the submission (Section 5).

\section{Setting the Right Framework: Terms of Reference}

It is important to set the correct framework within which to analyze the sale of state assets. This framework should ideally take into account wider public policy considerations relating to competition, efficiency, resource allocation and economic development. These wider considerations reflect the fact that the purpose of public policy should be to maximise societal welfare and a narrow focus on maximising revenue from the sale of state assets, particularly tangible assets, is likely to fail to adequately to reflect these issues.

The method chosen in Ireland to frame the debate was the creation of a review group to draw up a list of potential asset sales. Its terms of terms can be therefore be seen as framing the debate and depending on their scope and content as a suitable model to be employed elsewhere. Even if a review group is not created, the terms of reference could inform internal thinking within a finance department or subsequent consideration by a parliamentary committee.

The terms of reference for the Review Group of State Assets and Liabilities ("the Group") are as follows:

- To consider the potential for asset disposals in the public sector, including commercial state bodies, in view of the indebtedness of the State.

- To draw up a list of possible asset disposals.

- To assess how the use and disposition of such assets can best help restore growth and contribute to national investment priorities. 
- To review where appropriate, relevant investment and financing plans, commercial practices and regulatory requirements affecting the use of such assets in the national interest.

There is a clear preference for asset sales as a method of helping to resolve the indebtedness of the State. However, in considering asset sales the terms of reference suggest, quite properly, that wider considerations need to be taken into account. Drawing up a list of potential assets disposals implies setting criteria as to which assets should be sold. Furthermore, the terms of reference suggest that the asset sales should not only assist in resolving indebtedness, but also "help restore growth and contribute to national investment policies.” Finally, the terms of reference list a series of factors that may need to be taken into account when considering the use to which these assets are put. In sum, the terms of reference can be read as the maximisation of income from asset sales subject to a series of important wider public policy constraints. This is a sensible framework that permits consideration of the wider considerations identified above.

\section{Tangible Assets: Commercial State-Owned Firms.}

\section{Introduction}

Selling state assets is nothing new in Ireland, or in many other countries, particularly since the 1980s led by the UK (Vickers and Yarrow, 1988). The importance of state-owned firms in Ireland has declined, both in absolute and relative terms, since the early 1990s, due to a combination of privatisation and the growth in the economy. ${ }^{3}$ In the early 1980s state-owned firms employed 91,000 persons, accounting for 8 per cent of total employment in the economy; by 2008 employment declined to 41,000 persons in state-owned firms accounting for 2 per cent of total employment in the economy. ${ }^{4}$ The State exited ownership involvement in banking, ${ }^{5}$ telecommunications, steel, shipping and sugar refining. Nevertheless, what remains, as noted above, is state involvement in important sectors of the economy, some of which are competitive, others oligopolistic or monopolistic.

\footnotetext{
${ }^{3}$ For discussion see, for example, Palcic and Reeves (2004).

${ }^{4}$ Based on Barrington (1985, p. 289) and Forfas (2010, p. 3). The latter source contains an extensive discussion on the importance of state-owned firms to the economy.

${ }^{5}$ Until that is the financial crisis resulted in the State taking ownership in whole or in part in several banks.
} 
In considering which state-owned firms might be appropriately privatised, it is important to first examine the rationale for public ownership. If there are no strong or compelling reasons for public ownership, then the state-owned firm could be disposed of through privatisation. However, that is only a necessary, not a sufficient condition for privatisation. Attention has to be paid to the way in which the state-owned firm is privatised, especially when it has market power, to ensure that complementary policies are introduced so that the firm is subject to appropriate checks and balances. Even if these conditions are met there may be further barriers to successful privatisation which also need to be considered.

\section{Why Government Ownership?}

In considering whether or not a state-owned firm should be transferred to the private sector an important set of issues revolve around why the state-owned firm is in the public as opposed to the private sector. Thus the following questions need to be addressed:

- What purpose or rationale was there for the creation of the state-owned firm?

- Is that purpose or objective still relevant today?

- Will the transfer of the firm to the private sector damage the attainment of the objectives of public ownership?

- Are there better or more effective methods or instruments that could be used to attain those objectives?

Many state-owned firms were created many decades ago such as the Electricity Supply Board (“ESB”) in 1927, Bord na Mona in 1946, or Córas Iompair Éireann ("C IE"), ${ }^{6}$ in 1950 (Barrington, 1985, Appendix 1, pp. 308-311). Furthermore, in some instances, since the state-owned firm was created it has increased the range of activities in which it is involved. For example, while Bord na Mona was initially concerned with peat mining, it entered commercial and domestic waste management in 2007 with the acquisition of AES, which increased Bord na Mona's revenue by 20 per cent from activities in Ireland. ${ }^{7}$

The rationale as to why these activities were and are conducted within the public sector may no longer be relevant or valid and/or there may be better ways of attaining the objective. This may reflect technological change (e.g., the market has

\footnotetext{
${ }^{6} \mathrm{CIE}$ is responsible for the state's bus and rail services through separate companies. For details see http://www.cie.ie/about_us/chairmans_statement.asp. Accessed 10 September 2010.

${ }^{7}$ For details see Competition Authority (2007).
} 
expanded so much that there is room for many suppliers and thus the monopoly rationale for the state-owned firm is no longer valid); institutional reform (e.g., public private partnerships may be a much more appropriate and efficient procurement method than direct provision through state ownership); and, changes in ideology (e.g., a move away from a belief in protectionism, autarky and a distrust of the private sector towards reliance on a liberal open trading system and the efficacy of markets). ${ }^{8}$

Of course, this discussion assumes that the rationale(s) for public ownership is carefully specified in publicly available documents and, where there is more than one rationale, no conflicts occur. It also assumes that when a state-owned firm diversifies its activities - such as Bord na Mona in the above example - a similar exercise is conducted. Finally, it assumes that that there is no disparity between the publiclystated rationale and the underlying or 'real' rationale. In the case of Bord na Mona while the stated rationale for intervention is security of supply, ${ }^{9}$ arguable job creation is as, if not more, important motivation. ${ }^{10}$ It is not at all obvious that these conditions will always be met. Hence discovering why an activity is in the public realm is likely to be neither easy nor straightforward.

To some degree, however, this may not be an insuperable problem. In determining whether there is a valid rationale it is suggested that market failure framework be used. After all what is being compared are the merits of the public and the private sector. The framework is well developed and has been suggested by other commentators such as Forfas (2010, pp. 21-22) in the current debate over the role of state-owned firms. Nevertheless, there may be differences between the stated rationale for public ownership and those consistent with the market failure framework. The stated reasons reflect political decisions, where arguably concerns about re-election are uppermost, while the market failure approach is more about what politicians should do in order to maximise societal welfare (Gorecki, 2009).

The market failure framework suggests that following rationales for government intervention: ${ }^{11}$

\footnotetext{
${ }^{8}$ This change in view is consistent with the record in Ireland. See Barrett (2004) for a discussion on this point.

${ }^{9}$ This rationale is discussed further below.

${ }^{10}$ Indeed, Honohan (1997, p. 105) comments that peat-based electricity generation "can best be rationalised as an income redistribution measure.” Peat mining is of course an essential input into such generation.

${ }^{11}$ For a discussion of this framework, in the context of EU Structural Funds, see Honohan (1997, pp. 75-92).
} 
- Monopoly, combined with high barriers to entry, so that the firm has market power which can be used to raise prices above costs. Prices are too high with the result that consumers are worst off, either because they cannot purchase the product at the competitive level (due to a budget constraint) or they purchase the product but at too high a price;

- Externalities, prices are meant to reflect costs, but not all costs may be included in the price, such as the polluting activities of a factory or the noise imposed by an aircraft or highway vehicles on nearly residents; the water or air may be 'free' to the firm whereas it should be priced, with the result that there will be too much pollution and noise and water resources will be overexploited;

- Imperfect or asymmetric information, in that the seller or provider of a service or product possess knowledge not available to the buyer and that can be used to distort the buyers choice. Information can be provided to rectify the asymmetry;

- Public goods; that is, goods that are non-rivalrous and non-excludable. Nonrivalry means that consumption of the good by one individual does not reduce availability of the good for consumption by others; and non-excludability that no one can be effectively excluded from using the good. Examples often cited include security of supply (e.g. energy), clean air, free-to-air television, defence and lighthouses. ${ }^{12}$ Because the private sector will under provide such goods, because of the difficult of recouping the cost of provision, government could, for example, subsidise the activity or provide directly or under contract. These rationales, of course, only provide grounds for government intervention. They do not specify how the government should intervene. There is an extensive literature on the choice of instrument - public enterprise or tax or the creation of a property right or regulation or incorporation within a government department or a subsidy. ${ }^{13}$

Broadly speaking the result of the exercise examining why a firm is part of the public sector should result in state-owned firms being divided into three broad categories:

\footnotetext{
${ }^{12}$ However, it is not at all clear that lighthouses fall into this category. For a discussion, which refers to the experience of Great Britain and Ireland see Coase (1974).

${ }^{13}$ See for example, Trebilcock et al (1982) and Gorecki (2009).
} 
- those state-owned firms for which the stated rationale, whether or not it accords with the market failure framework set out above, is no longer relevant and valid and hence consideration can be given for privatisation. For example, Bord na Mona's peat mining for use in electricity generation may have been justified on grounds of security of supply, given Ireland's reliance in imported fuels. ${ }^{14}$ However, this rational may no longer be tenable, because of concerns about the environment - carbon dioxide emissions from peat are very high; and competitiveness - peat is high cost typically necessitating an annual surcharge on all electricity consumer (e.g. €78 million in 2010/11); while security of supply concerns are being addressed by other policy instruments - interconnection with Great Britain and the development of offshore gas resources; ${ }^{15}$

- those stated-owned firms for which the objectives, whether or not it accords with the market failure framework, can be met by more efficiently and effectively through the use of alternative policy instruments. For example, while urban bus services might have been run as a state-owned firm in order to assure supply and avoid inefficiencies/congestion with multiple providers on the same route, a better, more cost effective and flexible method of provision could be for a public authority to design the network of routes required but use competitive tendering to determine which firm would provide the service for a particular routes. Under this model the state-owned enterprise could compete for the right to supply the service, but would be competing against other suppliers. Such a tendering system has been used to determine, for example, which firm should operate the LUAS in Dublin; ${ }^{16}$ and,

\footnotetext{
${ }^{14}$ This interpretation is consistent with DCMNR (2007), EC (2001), and ESB (2005).

${ }^{15}$ For a discussion on these points see Tuohy et al (2009) and CER (2010). If a peat fired generating station's notified entitled costs are greater than its revenues then a surcharge - the Public Service Obligation - is levied; if its costs are less than its revenues, the difference is returned to the PSO fund. Typically it appears that monies are not returned.

${ }^{16}$ Another example might be ports, most of which are in public ownership. This is justified by reference to the fact that they are "essential pieces of national infrastructure and as such have a strategic role in facilitating both national and regional economic development" (Department of Transport, 2010, p. 7) and the need to "ensure that ... wider socio-economic interests are protected" (ibid, p. 9). However, arguably the same applies to Eircom and airlines, both of which are largely, if not entirely, in private hands. Furthermore in the 1990s (Industrial Policy Review Group, 1992, pp. 4546) and in the 2000s (Competition Authority, 2003, p. 3) concerns were expressed about the lak of competitiveness of Irish ports, which retarded rather than promoted economic development. As a result some attention is required as to why ports cannot be privatised, particularly the larger ones, and why these development and socio-economic interests - whatever they might be - cannot be safeguarded through other means.
} 
- those state-owned firms for which the objectives are best met through public ownership. The electricity and gas transmission and distribution networks are natural monopoly and there are arguably grounds for these remaining in public ownership.

The remainder of the discussion below discusses the factors that need to be taken into account in considering the first two options. ${ }^{17}$

Of course, it should be noted that it is possible that a large state-owned firm that is diversified and/or vertically integrated may as a result of this exercise be split up, with some parts remaining in the public sector and others in the private sector. It might be argued that the ESB, for example, was established as a public firm because of the need to control a monopoly supplier of electricity and in order to ensure rural electrification which might not otherwise be provided. However, electricity generation is rapidly becoming more competitive with entry of new generators and interconnection with other markets, with only transmission and distribution as a natural monopoly. Furthermore, the creation of the independent regulator, the Commission for Energy Regulation, addresses the problem of controlling the monopoly power that remains in the incumbent ESB. Indeed, a separate entity, EirGrid, controls and operates and will soon, unless government policy changes, own the transmission system, separate from ESB. Hence arguably, ESB generation activities could be privatised while the natural monopoly could remain within the public sector.

\section{Structurally Competitive vs Oligopolies/Monopolies}

The owner of a firm, whether in the public or private sector, monitors its performance and sets its goals and objectives, such as maximising profits or a profits break even target. Of course, in the private sector where the ownership of the firm may be widely held, management may play a larger role in setting policy, subject, of course, to the market for corporate control. ${ }^{18}$ Irrespective of whether or not the firm is part of the private or public sector, competitors will also impose constraints on the firm's behaviour, the strength of which depends on market characteristics. If the market has many competitors, with low barriers to entry, then any one firm is likely to

\footnotetext{
${ }^{17}$ A thorough review of state-owned firms would consider governance and other issues related to the third category. For a discussion of these issues see Forfas (2010).

${ }^{18}$ Mergers and acquisitions; the argument is that if firms become inefficient and/or do not maximise profits then another firm will acquire them and remove the inefficiency and maximise profits. For a discussion of the market for corporate control see Manne (1965).
} 
have little market power. Its competitors place constraints on its pricing and other dimensions of business behaviour. At the other extreme, if the firm is a monopoly in a market with high barriers to entry, then the firm will have market power, potentially at least, to charge prices above costs and generate excess profits which can be used for various purposes. In the latter case, with the state as owner, can in theory at least, constrain the pricing behaviour of the firm while if the firm were in the private sector it is much more likely to raise price above competitive levels.

This is, of course, very much a stylised picture of reality. In some structurally competitive markets such as inter-urban bus transport it is arguable that the market has not been competitive as they could be precisely because barriers to entry have been raised by restrictive licensing by government to protect the incumbent stateowned firm from competition. ${ }^{19}$ A recent example was the behaviour of the Minister for Transport with respect to licensing decisions biased in favour of Dublin Bus at the expense of a private bus operator, the Swords Express. ${ }^{20}$ Further in some of these markets the State is able to provide large levels of funding for firms that in part at least are involved in competition. CIE, for example, received a subsidy of $€ 316$ million in 2009, equivalent to 43 per cent of its revenue (CIE, 2010, p. 8). ${ }^{21}$ The bus subsidy runs for 5 years and was not put out to tender. ${ }^{22}$

Equally, a firm - irrespective or whether or not it is publicly or privately owned - with market power may use some of that power to earn supra normal profits, some of which may be dissipated in various forms of activity. When privately owned it might be used for corporate expenses and perks; in the public sector to keep open factories in a Minister's constituency in the $1980 \mathrm{~s}^{23}$ or to diversify into activities that may be politically popular but make little or no commercial or perhaps even

\footnotetext{
${ }^{19}$ Of course, this point should not be overstated as there are a litany of examples of the state supplying restrictive regulation to protect private firms. For a discussion see Gorecki $(2009,2010)$ and OECD (2001).

${ }^{20}$ For details see High Court, Digital Messenger Limited Trading As Swords Express and Minister for Transport and Dublin Bus [2010] IEHC 311, delivered on 30 July 2010. This judgment may be accessed

http://www.courts.ie/Judgments.nsf/bce24a8184816f1580256ef30048ca50/8f959bc0e75602c88025778 b003de28d?OpenDocument. Accessed 7 September 2010.

${ }^{21}$ The subsidy consists of a Public Service Obligation and Rail Safety Grant. The PSO was agreed with the bus services of CIE for five years, for rail for 10 years dating from December 2009.

${ }^{22}$ Another example is what Barrett (2006) refers to as the regulatory capture by the formerly $100 \%$ publicly-owned Aer Lingus of its parent department that over many decades refused to allow new entrants to compete with the national flag carrier until Ryanair was allowed to operate in 1986.

${ }^{23}$ On this see Sweeney (1960, p. 101).
} 
environmental sense (e.g., the promotion of electric cars by the ESB) or to allow monopoly rents to be captured in the form of higher labour costs (e.g. ESB). ${ }^{24}$

Nevertheless, the above characterisation does contain sufficient traction to provide some guidance as to the considerations that might be entertained when a state-owned firm is sold into the private sector. Essentially there should be complementary policies designed to ensure that the formerly state-owned firm should not be able to exercise market power and that as far as possible market forces should be used to allocate resources and set prices. This prevents the privatisation process from being nothing more than a transfer of a firm with market power from the public to the private sector. Such an approach has the advantage that it is consistent with the terms of reference for the Group which refer to helping restore growth and regulatory requirements. In order to ensure that resources are allocated as much as possible consistent with market forces the following options and considerations are recommended.

Break-up state-owned firms into monopoly and competitive parts where feasible.

If there are substantial economies of scope or vertical complementarities such an approach may be unduly costly. However, where this is not the case - arguably in the case of ESB discussed above - then such separation should be seriously considered. The competitive parts can be privatised and market forces will be sufficient to monitor performance while the monopoly element can be regulated. By engaging in this separation it makes the role of the regulator much easier since it precludes the monopolist from diverting profits into the competitive parts of the business or using the security of the regulated asset to engage in risky activities in other sectors of the economy. As noted above the ESB would be an instance where such restructuring could take place prior to privatisation. Another possible example would be the introduction of terminal competition at Dublin Airport, whereby each of the two terminals could be privatised but sold to different owners, or alternatively the terminals could be retained in public ownership but operating the terminals could be franchised out through a tendering process. ${ }^{25}$.

\footnotetext{
${ }^{24}$ On the latter point see Deloitte (2005, p. 10, p. 48, p. 224) and Diffney et al (2009, p. 481). The former source finds that labour costs in ESB are between 20 and $30 \%$ above comparable UK generators.

${ }^{25}$ Serious consideration was given to establishing a second terminal at Dublin Airport to compete with existing facilities (Panel, 2003), but this did not go ahead. On terminal competition see CAA (2005) which had previously been sceptical concerning airport terminal competition and CC (2009) which considers terminal competition in the context of BAA plc.
} 
Remove unnecessary entry and other restrictions used to protect the incumbent stateowned firm.

To the extent that entry and other regulations are used to protect a state-owned firm from competition, as arguably is the case in urban and to a lesser extent interurban bus services, then these restrictions should be abolished as part and parcel of any transfer of assets to the private sector. Of course, abolition of such restrictions should be part of any sensible policy to improve the efficiency of the economy, irrespective of the ownership issue. While some steps have been made in this direction on foot of the OECD (2001) report on this issue and a series of reports on the professions by the Competition Authority, ${ }^{26}$ much remains to be done as discussed elsewhere in this paper in specific instances.

Competition for the market rather than competition in the market.

In some instances the problems created by a monopoly situation, based on economies of scale, scope and/or density can be resolved by instituting competition for the market through a tendering procedure, rather than the creation of a regulatory agency to supervise competition in the market. A good example of competition for the market is household waste collection, where the evidence suggests that contracting out the right to collect such waste secures the lowest price, compared to a situation of an unregulated state-owned monopolist (Competition Authority, 2002). Recent government policy announcements are moving towards tendering for waste collection (DoEHLG, 2010, pp. 13-14). Franchising bus routes is another example. In 2002 the Minister for Transport announced that $25 \%$ of the bus routes in Dublin would be franchised from 2004 with the implication of more to follow (Department of Transport, 2002, pp. 5-6). However, despite compelling arguments ${ }^{27}$ for such a move, by 2010 there were no franchised routes.

$\underline{\text { Regulation as a last resort. }}$

Where none of the above measures to introduce competition are likely to be successful and the firm has market power then the firm should be subject to regulation. There are many examples of regulatory structures in Ireland to select from in coming to a view as to which is the most appropriate model to follow. Indeed, in most cases the state-owned firm is already subject to regulation such as ESB and Bord Gais by the Commission of Energy Regulation, which begs the obvious question that

\footnotetext{
${ }^{26}$ Full details may be found on the Competition Authority’s website: www.tca.ie.

${ }^{27}$ See, for example, Massey (2007).
} 
if the original motivation for public ownership was to control the monopoly problem, why is both state ownership and regulation necessary? Given the necessity of independent regulation under EU Directives and Regulations relating, to for example, telecommunications, gas and electricity, it is clear that public ownership is the weaker constraint. $^{28}$

\section{$\underline{\text { Resolution or Step-in Rights. }}$}

Large firms with potential market power are difficult to regulate for a whole host of reasons from asymmetric information to the ability to funnel resources from regulated to unregulated activities. One difficulty is that the regulated firm may take on excessive leverage and use its inability to raise additional funds for vital infrastructure investment to argue that it should receive lenient regulatory treatment. Similarly, the firm might undertake risky diversification, end up in financial or other difficulties and request a price increase to fund such errors. Since many regulated firms with market power provide important services essential to the everyday functioning of the economy, if these firms were to be become bankrupt or unexpectedly stop supplying services - even for a short time - then this could have substantial adverse effects on the economy. Thus the regulated firm is in a strong bargaining position when it asks the regulator for a price increase, implicitly threatening bankruptcy and discontinuity of service if it is not granted.

In order to level the regulatory playing field when the state-owned firm is privatised one option would be to allow the regulator to step in, run the firm and dispose of the assets as the regulator saw fit, if the regulated entity failed to meet the conditions set out in its license. ${ }^{29}$ Of course, the regulator would not be required to run the regulated firm itself; it could appoint a trustee. One such model is that applied by the Irish financial regulator, which recently appointed a trustee to run Quinn Insurance where there were concerns about the financial viability of the firm. ${ }^{30} \mathrm{~A}$

\footnotetext{
${ }^{28}$ On electricity see, for example, Article 35 of Directive 2009/72/EC concerning common rules for the internal market in electricity, of 13 July 2009.

${ }^{29}$ The license might for example set out a programme of investment that is expected and as well as the regulatory regime that will be imposed in the regulated entity. If the regulated entity is unable to meet the investment programme because it has incurred too much debt then step in rights might be invoked. Of course, holders of debt would be aware of this possible problem and thus this acts as a disincentive for the regulated entity to market such debt.

${ }^{30}$ Quinn Insurance Limited (“QIL”), a major Irish insurer, was according to the Financial Regulator involved in serious and persistent breaches of its solvency requirements. As a result the Financial Regulator, in the interests of policyholders, applied to the High Court in March 2010 for the appointment of joint administrators to manage the insurer. Subsequently QIL consented to these
} 
similar option is to put in place some form of Special Administration regime, whereby continuity of service may be better protected than it would be in standard bankruptcy proceedings. $^{31}$

One of the implications of the above approach to privatising any state assets is that the price will be lower than it otherwise would be. Monopolies, even publicly owned, tend to be worth more than if divided into a series of smaller firms required to compete with each other. Equally, removal of entry controls will increase competition and likely lower the returns from asset sales. On the other hand, changes that reduce the constraints on management (with respect to workers, sourcing input, investment and so on) will increased the market value of the firm. The terms of reference for the Group envisage other factors being taken into account and hence the above considerations are relevant.

\section{Barriers to Reform: Compensating the Losers?}

No matter how thorough the analyses of whether a state-owned firm should remain in public ownership some will argue against the sale of assets to the private sector. The sale might be characterised as needlessly selling off the family silver, either because the price is too low with the current depressed state of the economy or on principle. Alternatively those that manage and work for state-owned firms may argue against the sale of such firms, because they may currently benefit from the present arrangements. However, unlike the first group, those employed in stateowned firms have the power to resist the transfer of state assets to the private sector through strikes and other action. Attempts to franchise out bus routes in Dublin in 2002 were abandoned after the bus unions objected while the Irish Congress of Trade Unions ("ICTU”) ${ }^{32}$ stated, together with reforms of CIE, franchising would threaten the survival of social partnership (Massey, 2006, p.1). These groups are likely to make change difficult. They are concentrated and well organised, while the beneficiaries of change - society at large through a more efficient allocation of resources and a more competitive economy - are dispersed and much less effective at organising. Furthermore the State has created institutional mechanisms - Employee Share Ownership Plans (“ESOP”) which also make privatisation more difficult.

appointments. For details see the Financial Regulator's website:

http://www.financialregulator.ie/Pages/home.aspx. Accessed 10 September 2010.

${ }^{31}$ See, for example. Helm (2008).

32 The ICTU is an umbrella grouping representing trade unions. For further information see its website: http://www.ictu.ie/about/. Accessed 10 September 2010. 


\section{Rent collection.}

Firms with durable market power are able to charge a price above the competitive level without attracting entry to compete away that price/cost margin, where the margin includes a normal rate of return. Indeed, that is the definition of market power. Frequently the rent - the difference between the competitive and the monopoly return - is captured in part by labour through higher wages and/or inefficient work and other practices. In the case of ESB its labour costs would appear to be substantially above those of electricity systems where there is more competition, while there is also evidence of over manning (Deloitte, 2005; Diffney et al, 2009). Transferring these functions to the private sector while at the same time introducing mechanisms such as those suggested above to facilitate greater competition means that these rents will be competed away. ${ }^{33}$ Under these conditions employees and management, which is also likely to be sharing in these rents, will strongly resist a simultaneously switch in ownership and competitive conditions. Furthermore, Ministers who are able to influence the behaviour of the state-owned firms as a method for implementing their policy preferences - particularly in depressed times - may be reluctant to support privatisation.

\section{Employee Share Ownership Plans (ESOPs).}

While rent collecting by labour and others is nothing unusual in advanced countries when it comes to state-owned enterprises, the creation of Employee Share Ownership Plans or ESOPs are by all accounts unique to Ireland. ESOPs are owned by the employees of the state-owned firm and on occasion are entitled to nominate a member to the board. ${ }^{34}$ The ESOP is awarded shares in the state-owned firm either free or at a substantial discount. ${ }^{35}$ In some instances the ESOP is created when the state-owned firm is privatised, where the shares held by the ESOP typically account for just under $15 \%$ of the company (Palcic \& Reeves, 2004, Table 11, p. 20), or while it is still in state ownership, where the ESOP's ownership is 5\% or less. ${ }^{36}$ The sums

\footnotetext{
${ }^{33}$ Of course, introducing market mechanisms to increase competition is likely to reduce if not eliminate rents irrespective of ownership; however, that does not necessarily prevent the return to capital be captured by labour, which would be much less likely under private compared to public ownership.

${ }^{34}$ See, for example, the ESOP for ESB. For details see: http://www.esbesop.ie/faq.html\#14. Accessed 23 September 2010.

${ }^{35}$ For the ESOPs involved in privatised state-owned firms, 5\% of the shares were given free in exchange for changes in work practices and voluntary redundancies, with the remaining 9.9\% was purchased by the ESOP at a discounted price. Palcic \& Reeves (2004, p. 20).

${ }^{36}$ The percentage of the capital stock distributed is less for those state-owned firms which are still in public ownership. In 2008 the ESOP for Bord Gais was incorporated and by 2009 accounted for 3.29\%
} 
transferred, for selected privatisations up to 2002, are considerable: from €83,161 per ESOP member in the case of Eircom to $€ 27,522$ per ESOP member in the case of ACC Bank (ibid., Table 11, p. 20). At least three issues arise with respect to the privatisation of state owned firms and ESOPs.

First, it is not entirely clear what the rationale for this transfer of wealth from society at large to a select group of individuals who happen to be lucky enough to work for the state-owned firm. It appears to consist of two parts: first, in return for work place changes and increased flexibility (ibid, p. 20); ${ }^{37}$ and second, a payment not to attempt to block privatisation. It is not at all clear how close is the relationship between the value of the shares awarded free to the ESOP and the value of the increased flexibility, since in all the ESOPs analysed by Palcic and Reeves (ibid., p.20) bar one, $5 \%$ of shares of the privatised firm are allocated for this purpose. The same percentage was awarded in the case of the ESB ESOP although the percentage was a little lower for the Bord Gais ESOP (3.29\%). Recall that the employees of the state-owned firm are likely to be already collecting a wage premium and/or have restrictive practices so it not clear that these awards are appropriate.

Second, ESOPs lead to a reduction in the return for the exchequer when the firm is sold. This is in two parts: the awarding of free and discounted shares; and subsequently favourable tax treatment of the ESOP when the newly privatised firm acquired by another firm. ${ }^{38}$ Third, ESOPs have a considerable influence over the running of the newly privatised firm as well as existing state-owned firms. The ESOPs incentives may not always be aligned with management in terms of improving efficiency and competitiveness. As a result ESOPs may affect the market for corporate control. The discipline that comes from the threat of takeover may be weaker than it otherwise would be. ${ }^{39}$

Thus the Group will need to carefully consider whether the continued transfer of public assets together with future constraints on management are merited in any

of its capital stock. This was given in return for "transformational savings" (Bord Gais, 2010, p. 7). In contrast the ESOP for ESB own 5\% of the capital stock of the state-owned company. The ESOP was part of the Cost and Competitiveness Review agreed between the Government, ESB management and the ESB group of unions in 1996. Legislation creating the ESOP was passed in 2001 enabling the roll out of the ESOP. For further details see: http://www.esbesop.ie/index.html. Accessed 7 September 2010.

${ }^{37}$ See also previous footnote.

${ }^{38}$ This has been the record with respect to Eircom.

${ }^{39}$ For example, the Employee Share Ownership Trust of Aer Lingus voted against a takeover bid from Ryanair; see http:/www.rte.ie/news/2006/1122/aerlingus.html. 
future privatisation. In our view it is difficult to justify such a transfer of assets, especially in the midst of a recession with public expenditure subject to extreme pressures. Any transfers to ESOPs in exchange for flexibility should reflect the value of these concessions, determined by an independent source, taking into account any wage premium already present. There should be no bribes for the switch of assets from the public to the private sector.

\section{Intangible Assets: Property Rights}

\section{Introduction}

Intangible assets such as radio spectrum licences, mobile phone licences, oil drilling permits, wind turbine permits ${ }^{40}$ and carbon dioxide emission permits are likely to be valuable property rights. So are brand recognition and know-how. This reflects their scarcity value. Demand exceeds supply, which is limited for technological, public policy, geological, economic or social reasons. The issue thus becomes how to allocate these scarce resources. Three options are considered: auctions; beauty contests; and, free allocation. The discussion suggests that auctions, suitable designed, are the most appropriate solution for allocating intangible assets.

\section{Auctions}

Typically scarce resources, whether it is an Auguste Renoir or a Jack Yeats painting or the right to drill for oil and gas in the North Sea, are sold to the highest bidder. This reflects their scarcity value. Any price less than this implies a transfer from the seller to the buyer, in the case of publicly owned property rights, from the State to the oil exploration firm or the radio station operator or the mobile phone operator. The UK Government, for example, auctions carbon allowances under the EU ETS to the highest bidder, because it "is consistent with providing value for money to the taxpayer, subject to the process being transparent, resilient and secure” DEFRA, 2007). ${ }^{41}$ Perhaps the most famous example of an auction by a government was the UK auction of $3 G$ telecom licences, which raised Stg£22.5 billion or 2.5\% of

\footnotetext{
${ }^{40}$ Wind is a common property resource that is the property of the people of Ireland. It is a scarce resource since some sites are better than others and, as such, is likely to command a positive price, particularly in view of the assumption by electricity consumers of the downside risk in the price of wind-generated electricity through the REFIT programme which, in 2010/11, cost consumers €29 million (CER, 2010, p. 18). In addition, there is a possibility that wind generated electricity may be exported from Ireland to Great Britain with the rents from wind accruing to the owners of the right to generate wind power, not consumers or taxpayers in Ireland.

${ }^{41}$ Note that Ireland has irreversibly foregone the right to auction emission permits until 2012, when the right to auction permits is the responsibility of the EU.
} 
UK GNP or enough to build 400 hospitals. Germany was also successful in raising substantial sums in its 3G auction (Binmore \& Klemperer, 2002).

Designing an auction requires careful attention to the way it is structured such that the desired outcome is reached. The 3G auction referred to above employed a team of experts to design the auction with considerable success. Other countries were less successful in their design. Nevertheless, there is substantial expertise and experience to draw on with respect to the theory (e.g., Klemperer, 2004) and practice (e.g. Matthes \& Neuhoff, 2007 on carbon permit auctions). It should be noted that in designing auctions, as with the discussion above on state-owned firms, attention needs to be paid to competition issues. For example, if a market is dominated by a small number of players then there might be a case for reserving one slot for a new entrant; this also has the advantage that it might make it more difficult for the existing players to game the auction.

Recently the Commission for Communications Regulation (“ComReg”), which regulates telecommunications in Ireland, issued a consultation paper on the allocation of 900 and $1800 \mathrm{MHz}$ spectrum in which different types of auctions are proposed (ComReg, 2009). The final outcome is however, dependent on the consultation process. In any event this is in contrast to the beauty parade combined with administrative fee option selected with respect to the allocation of $3 G$ licenses earlier in the decade and discussed below.

\section{Beauty Contests or Parades ${ }^{42}$}

Scarce rights can be allocated on the basis of what is sometimes referred to as a beauty parade. This is akin to a form of barter. Some non-price criteria are set out for the awarding of the property right possibly combined with a minimum payment. The criteria might include some things thought worthy from a public policy point of view or at least the preferences of the body awarding the property right. However, these need to be weighed and each contestant needs to evaluated, a potentially time consuming and opaque process that can easily lead to charges of favouritism and corruption. Furthermore beauty contests, when combined with an administrative fee, are likely to result in considerable forgone revenue compared to an auction. Five of the seven EU countries that auctioned 3G licences earned more, after adjusting for population size, than the $€ 249$ million administrative fee that Ireland earned as part of

\footnotetext{
${ }^{42}$ See Binmore \& Klemperer (2002, pp. C76-C77) and NAO (2001, p. 44).
} 
its beauty parade. $^{43}$ The amount earned depended on auction design (UK vs. Netherlands) and the timing in relation to the internet stock bubble (UK \& Germany vs. Switzerland \& Belgium).

\section{Free Allocation}

The third alternative is simply to give the asset away free. While this is perhaps unusual, there are nevertheless some instances of this. For example, under the EU ETS Member States can elect to auction off 10\% of the allowances. Ireland chose not to, with the result that the forgone revenue in 2008 would have been $€ 36$ million (Gorecki et al, 2009, p. 25). ${ }^{44}$ It is not obvious why valuable assets should be given away free. To the extent that there are some implicit criteria for allocating these property rights then they fall into the same category as beauty contests.

\section{Intangible Assets and Tangible Assets}

In some instances, government agencies and quasi-governmental organisations have build up a considerable amount of know-how and substantial brand recognition in delivering a range of services to (parts of) the public. Incorporation of such agencies and organisations would instantly improve the government's balance sheet. ${ }^{45}$ It would also open the door to a discussion which services are primarily in the public interest - and should therefore be financed from the public purse and perhaps provided by a state-owned company - and which serve primarily private interests and therefore should recover a share of their costs through fees, be mutualised, or privatised. Examples include the sales promotion activities of Bord Bia and Failte Ireland; and the consulting services of and the Sustainable Energy Authority of Ireland and Teagasc, the Irish Agriculture and Food Development Authority.

\footnotetext{
${ }^{43}$ ComReg awarded three $3 G$ licenses in 2002 with a present value of $€ 175$ million. The nominal value was €279.3 million. In 2005 a fourth licence was issued, bring the total raised to $€ 249$ million in present value terms or $€ 393.6$ million in nominal terms. (Based on various ComReg press releases (e.g, Director of Telecommunications Regulation (2002)), Annual Reports and discussions). In the UK the $3 G$ licences yielded about $€ 670$ per head, Germany €620, Italy €220, Netherlands €180, Austria €90, Belgium €50, and Switzerland €30 (NAO, 2001, Figure 7, p. 19, which refers to licences issued up to March 2001). Ireland's population in 2002 was 3.9 million, with revenue per head of $€ 64$, higher than Belgium but lower than Austria.

${ }^{44}$ In 2010, emissions regulated by the EU ETS amount to about 15 million tonnes of carbon dioxide; the current spot price is $€ 14 / \mathrm{tCO}_{2}$.

${ }^{45}$ Note that this may not reduce borrowing costs if potential lenders deduct the now-explicit assets from the implicit assets.
} 


\section{Conclusions}

The debate over the potential saleability of certain tangible and intangible assets owned by the state turns into much more than an exercise in ranking these assets by commercial viability and value. Careful attention needs to be devoted to ensuring that wider public policy considerations are taken into account, such competition, regulation and economic development. Hence it is important to formulate terms of reference for any consideration of the sale of state assets that reflect these wider concerns.

In the case of tangible assets - commercial state firms - the debate is around whether these firms should be the public sector and whether the objectives can be better met by alternative arrangements. In privatising these state-owned firms careful attention needs to be paid to ensure that markets are well organised and competitive. This may necessitate for example breaking up a vertically integrated firm into its competitive and monopoly parts. To a considerable degree the debate over privatisation reflects issues related to the regulatory reform agenda. But in both cases what is on offer is a more efficient and competitive economy if reform is conducted sensibly and is not derailed by vested interests as has been the case, on occasion, in the past.

In terms of intangible assets such as permits of various kinds such a those relating to carbon emissions, wind turbines and oil exploration as well as radio spectrum licences, the conclusion is much more straightforward: these assets should be auctioned off to the highest bidder, but using a carefully designed auction which needs to take into account the competitive situation amongst the bidders not only to prevent collusion and gaming, but also to encourage entry and competition. Another important reason to auction these assets is that there is a danger, absent auctioning, that government will be unaware that these are valuable assets and hence not properly price them when making public policy decisions. 


\section{REFERENCES}

BARRETT, S. D. 2004. Privatisation in Ireland. CESifo Working paper No. 1170.

BARRETT, S. D. 2006. "Commercialising a national airline - the Aer Lingus case study.” Journal of Air Transport Management. Vol. 12, pp. 159-167.

BARRINGTON, T. J. 1985. "Public Enterprise in Ireland." Annals of Public and Co-operative Economy. Vol. 56, Issue 3, July-Sept, pp. 287-331.

BINMORE, K. \& P. KLEMPERER. 2002. "The Biggest Auction Ever: The Sale of the British 3G Telecom Licences.” Economic Journal. Vol. 112, March, pp. C74-C96.

BORD GAIS. 2010 Meeting Your Changing Gas and Electricity Needs. Annual Report and Financial Statement 2009. Cork: Bord Gais.

CIE. 2010. Driving Efficiency. Annual Report and Accounts 2009. Dublin: CIE.

CIVIL AVIATION AUTHORITY (“CAA”) 2005. Airports Review - Policy Issues. A Consultation Paper. London: CAA.

COASE, R. H. 1974. "The Lighthouse in Economics." Journal of Law and Economics. Vol. 17, No. 2, October, pp. 357-376.

COMMISSION FOR COMMUNICATIONS REGULATION (“ComReg”). 2009. Liberalising the Future Use of the $900 \mathrm{MHz}$ and $1800 \mathrm{MHz}$ Spectrum Bands and Spectrum Release Options, Response to Consultation 09/14 and Further Consultation. Document No. 09/14. Dublin: ComReg

COMMISSION FOR ENERGY REGULATION (“CER”). 2010. Public Service Obligation Levy 2010/2011. CER/10/131. Dublin: CER.

COMPETITION AUTHORITY. 2002. Alleged Excessive Pricing by Greenstar Recycling Holdings Limited in the Provision of Household Waste Collection Services in Northeast Wicklow. Enforcement Decision Series No. E/05/002. Dublin: the Authority.

COMPETITION AUTHORITY. 2003. Submission to the Department of the Communications, Marine and Natural Resources on the findings and recommendations of the High Level Review of Ports. Submission No. S/03/003. Dublin: the Authority.

COMPETITION AUTHORITY. 2007. Determination of Merger Notification M/0 7/012 - Bord na Mona/AES. Dublin: the Authority.

COMPETITION AUTHORITY. 2008. Determination of Merger Notification M/08/009 - Kerry/Breeo. Dublin: the Authority. 
COMPETITION COMMISSION (CC). 2009. "Introducing terminal competition at BAA’s UK airports.” In CC (2009) BAA Airports market investigation. London: CC. Annex 10.11

DELOITTE AND TOUCHE LLP (“DELOITTE”). 2005. Final Report. A Review of the Electricity Sector in Ireland. A Report Prepared for the Minister for Communications, Marine and Natural Resources. Dublin: Deloitte.

DEPARTMENT OF ENVIRONMENT, FOOD AND RURAL AFFAIRS ("DEFRA"). 2007. Consultations on Proposed UK Auction Design for Use During Phase II. EU Emissions Trading Scheme. London: DEFRA.

DEPARTMENT OF COMMUNICATIONS, MARINE AND NATURAL RESOURCES (“DCMNR”). 2007. Delivering a Sustainable Energy Future for Ireland. The Energy Policy Framework 2007-2020. Dublin: Stationery Office.

DEPARTMENT OF ENVIRONMENT, HERITAGE AND LOCAL GOVERNMENT (“DoEHLG”). 2010. Draft Statement of Waste Policy - For Consultation. Dublin: the Department.

DEPARTMENT OF TRANSPORT. 2002. Statement on Public Transport Reform by Seamus Brennan, T.D., Minister for Transport. Dublin: the Department.

DEPARTMENT OF TRANSPORT. 2010. Ports Policy Review Consultation Document. Dublin: the Department.

DIFFNEY, S., J. FITZ GERALD, S. LYONS, \& L. MALAGUZZI VALERI. 2009. "Investment in Electricity Infrastructure in a Small Isolated Market: the Case of Ireland.” Oxford Review of Economic Policy. Vol. 25, No. 3, pp. 469-487.

EUROPEAN COMMISSION (“EC”). 2001. State Aid N 6/A/2001 - Ireland. Public Service Obligation Imposed on the Electricity Supply Board with Respect to the Generation of Electricity Out of Peat. C(2001) 3265. Brussels: the Commission.

ESB. 2005. "Minister for Finance Opens new Midlands Peat Generating Station.” Press Release. 21 April.

FORFAS. 2010. The Role of State Owned Enterprises: Providing Infrastructure and Supporting Economic Recovery. Dublin: Forfas.

GORECKI, P. K. 2009. "The Recession, Budgets, Competition, and Regulation: Should the State Supply Bespoke Protection?” in T. Callan (ed). Budget Perspectives 2010. Research Series No. 12. Dublin: ESRI, pp. 19-53.

GORECKI, P. K. 2010 “Do you believe in magic? Improving the quality of pharmacy services through restricting entry and aspirational contracts, the Irish experience.” European Journal of Health Economics. Published online 9 July 2010. 
GORECKI, P., S. LYONS \& R. J. TOL (2009) EU Climate Change Policy 20132020: Thoughts on Property Rights and Market Choices. Working Paper 292. Dublin: ESRI.

HELM, D., 2008. “Special administration, financing functions and utility regulation”, Commentary, 23 October. This may be accessed at:, http://www.dieterhelm.co.uk/sites/default/files/Commentary_Oct08.pdf

HONOHAN, P. (ED) 1997. EU Structural Funds in Ireland. A Mid-Term Evaluation of the CSF 1994-1999. Policy Research Series Paper No. 31. Dublin: ESRI.

INDUSTRIAL POLICY REVIEW GROUP. 1992. A Time for Change: Industrial Policy for the 1990s. Dublin: Stationery Office.

KLEMPERER, P. 2004. Auctions: Theory and Practice. Princeton: Princeton University Press.

MALAGUZZI VALERI, L. 2009. "Welfare and Competition Effects of Electricity Interconnection Between Ireland and Great Britain.” Energy Policy. Vol. 37, Issue 11, Nov, pp. 4679-4688.

MANNE, H. 1965. “Mergers and the Market for Corporate Control.” Journal of Political Economy. Vol. 73, No. 2, April, pp. 110-120.

MASSEY, P. 2007. "Delayed Indefinitely. Regulatory Reform of the Irish Bus Industry.” ESRI Quarterly Economic Commentary, Spring, pp. 38-61.

MATTHES, F., \& K. NEUHOFF 2007. Auctioning in the European Union Emissions Trading Scheme. Final Report Commissioned by WWF. Berlin/Cambridge Oko-Instit e.V/University of Cambridge.

NATIONAL AUDIT OFFICE. 2001. The Auction of Radio Spectrum for the Third Generation of Mobile Phone Telephones. London: the Stationery Office.

DIRECTOR OF TELECOMMUNICATIONS REGULATION. 2002. "3 Companies Apply for 3G Licences.” Media Release 27 March.

OECD. 2001. Regulatory Reform in Ireland. OECD Reviews of Regulatory Reform. Paris: OECD.

PALCIC, D., \& E. REEVES. 2004. “An Economic Analysis of Privatisation in Ireland 1991-2003." Journal of the Statistical and Social Inquiry Society of Ireland. Vol. XXXIV, pp. 1-27.

PANEL. 2003. Dublin Airport - Review of Expressions of Interest for an Independent Terminal. Report to the Minister of Transport. Dublin: Department of Transport. This may be accessed at: http://www.courts.ie/Judgments.nsf/bce24a8184816f1580256ef30048ca50/8f95 9bc0e75602c88025778b003de28d?OpenDocument. 
SWEENEY, P. 1990. "Public Enterprise in Ireland. A Statistical Description and Analysis.” Journal of the Statistical and Social Inquiry Society of Ireland. Vol. XXVI, Part II, pp. 69-117.

TREBILCOCK, M.J., D. J. HARTLE, J.R.S. PRICHARD, \& D. N. DEWEES. 1982. The Choice of Governing Instrument. A study prepared for the Economic Council of Canada. Ottawa: Supply \& Services Canada.

TUOHY, A. ET AL. 2009. "Burning Peat in Ireland: An Electricity Market Dispatch Perspective.” Energy Policy. Vol. 37, Issue, 8, August, pp. 3035-3042.

VICKERS, J. \& G. YARROW. 1988. Privatization: An Economic Analysis. Cambridge, Mass: MIT Press. 


\begin{tabular}{|c|c|c|}
\hline Year & Number & $\begin{array}{l}\text { Title/ Author(s) } \\
\text { ESRI Authors/ Co-authors /talicised }\end{array}$ \\
\hline \multicolumn{3}{|l|}{2010} \\
\hline & 355 & $\begin{array}{l}\text { The Impact of I reland's Recession on the Labour } \\
\text { Market Outcomes of its I mmigrants } \\
\text { Alan Barrett and Elish Kelly }\end{array}$ \\
\hline & 354 & $\begin{array}{l}\text { Research and Policy Making } \\
\text { Frances Ruane }\end{array}$ \\
\hline & 353 & $\begin{array}{l}\text { Market Regulation and Competition; Law in } \\
\text { Conflict: A View from Ireland, Implications of the } \\
\text { Panda J udgment } \\
\text { Philip Andrews and Paul K Gorecki }\end{array}$ \\
\hline & 352 & $\begin{array}{l}\text { Designing a property tax without property } \\
\text { values: Analysis in the case of Ireland } \\
\text { Karen Mayor, Seán Lyons and Richard S.J. Tol }\end{array}$ \\
\hline & 351 & $\begin{array}{l}\text { Civil War, Climate Change and Development: A } \\
\text { Scenario Study for Sub-Saharan Africa } \\
\text { Conor Devitt and Richard S.J. Tol }\end{array}$ \\
\hline & 350 & $\begin{array}{l}\text { Regulating Knowledge Monopolies: The Case of } \\
\text { the IPCC } \\
\text { Richard S.J. Tol }\end{array}$ \\
\hline & 349 & $\begin{array}{l}\text { The Impact of Tax Reform on New Car Purchases } \\
\text { in I reland } \\
\text { Hugh Hennessy and Richard S.J. Tol }\end{array}$ \\
\hline & 348 & $\begin{array}{l}\text { Climate Policy under Fat-Tailed Risk: } \\
\text { An Application of FUND } \\
\text { David Anthoff and Richard S.J. Tol }\end{array}$ \\
\hline & 347 & $\begin{array}{l}\text { Corporate Expenditure on Environmental } \\
\text { Protection } \\
\text { Stefanie A. Haller and Liam Murphy }\end{array}$ \\
\hline & 346 & $\begin{array}{l}\text { Female Labour Supply and Divorce: New } \\
\text { Evidence from Ireland } \\
\text { Olivier Bargain, Libertad González, Claire Keane } \\
\text { and Berkay Özcan }\end{array}$ \\
\hline & 345 & $\begin{array}{l}\text { A Statistical Profiling Model of Long-Term } \\
\text { Unemployment Risk in I reland }\end{array}$ \\
\hline
\end{tabular}


Philip J. O'Connell, Seamus McGuinness, Elish Kelly

The Economic Crisis, Public Sector Pay, and the Income Distribution

Tim Callan, Brian Nolan (UCD) and John Walsh

Estimating the Impact of Access Conditions on Service Quality in Post Gregory Swinand, Conor O'Toole and Seán Lyons

The Impact of Climate Policy on Private Car Ownership in I reland Hugh Hennessy and Richard S.J. Tol

$341 \quad$ National Determinants of Vegetarianism Eimear Leahy, Seán Lyons and Richard S.J. Tol

An Estimate of the Number of Vegetarians in the World

Eimear Leahy, Seán Lyons and Richard S.J. Tol

International Migration in I reland, 2009 Philip J O'Connell and Corona Joyce

The Euro Through the Looking-Glass:

Perceived Inflation Following the 2002 Currency Changeover

Pete Lunn and David Duffy

Returning to the Question of a Wage Premium for Returning Migrants Alan Barrett and Jean Goggin

What Determines the Location Choice of Multinational Firms in the ICT Sector? I ulia Siedschlag, Xiaoheng Zhang, Donal Smith

Cost-benefit analysis of the introduction of weight-based charges for domestic waste - West Cork's experience Sue Scott and Dorothy Watson

The Likely Economic Impact of Increasing Investment in Wind on the Island of I reland Conor Devitt, Seán Diffney, John Fitz Gerald, Seán Lyons and Laura Malaguzzi Valeri 
Estimating Historical Landfill Quantities to Predict Methane Emissions Seán Lyons, Liam Murphy and Richard S.J. Tol

International Climate Policy and Regional Welfare Weights

Daiju Narita, Richard S. J. Tol, and David Anthoff

A Hedonic Analysis of the Value of Parks and Green Spaces in the Dublin Area Karen Mayor, Seán Lyons, David Duffy and Richard S.J. Tol

Measuring International Technology Spillovers and Progress Towards the European Research Area Iulia Siedschlag

Climate Policy and Corporate Behaviour Nicola Commins, Seán Lyons, Marc Schiffbauer, and Richard S.J. Tol

The Association Between Income Inequality and Mental Health: Social Cohesion or Social Infrastructure Richard Layte and Bertrand Maître

A Computational Theory of Exchange:

Willingness to pay, willingness to accept and the endowment effect

Pete Lunn and Mary Lunn

Fiscal Policy for Recovery John Fitz Gerald

The EU 20/20/2020 Targets: An Overview of the EMF22 Assessment

Christoph Böhringer, Thomas F. Rutherford, and Richard S.J. Tol

Counting Only the Hits? The Risk of Underestimating the Costs of Stringent Climate Policy Massimo Tavoni, Richard S.J. Tol

International Cooperation on Climate Change Adaptation from an Economic Perspective Kelly C. de Bruin, Rob B. Dellink and Richard S.J. 
The Public-Private Sector Pay Gap in I reland:

What Lies Beneath?

Elish Kelly, Seamus McGuinness, Philip O'Connell

A Code of Practice for Grocery Goods Undertakings and An Ombudsman: How to Do a Lot of Harm by Trying to Do a Little Good Paul K Gorecki

Negative Equity in the I rish Housing Market David Duffy

Estimating the I mpact of Immigration on Wages in I reland

Alan Barrett, Adele Bergin and Elish Kelly

Assessing the Impact of Wage Bargaining and Worker Preferences on the Gender Pay Gap in Ireland Using the National Employment Survey 2003

Seamus McGuinness, Elish Kelly, Philip O'Connell, Tim Callan

Mismatch in the Graduate Labour Market Among Immigrants and Second-Generation Ethnic Minority Groups

Delma Byrne and Seamus McGuinness

Managing Housing Bubbles in Regional Economies under EMU: I reland and Spain Thomas Conefrey and John Fitz Gerald

J ob Mismatches and Labour Market Outcomes Kostas Mavromaras, Seamus McGuinness, Nigel O'Leary, Peter Sloane and Yin King Fok

Immigrants and Employer-provided Training Alan Barrett, Séamus McGuinness, Martin O'Brien and Philip O'Connell Differentials in Perinatal Mortality in I reland? 
Richard Layte and Barbara Clyne

311

Exploring International Differences in Rates of Return to Education: Evidence from EU SILC Maria A. Davia, Seamus McGuinness and Philip, J. O'Connell

Car Ownership and Mode of Transport to Work in Ireland

Nicola Commins and Anne Nolan

Recent Trends in the Caesarean Section Rate in Ireland 1999-2006

Aoife Brick and Richard Layte

Price Inflation and Income Distribution Anne Jennings, Seán Lyons and Richard S.J. Tol

Overskilling Dynamics and Education Pathways Kostas Mavromaras, Seamus McGuinness, Yin King Fok

What Determines the Attractiveness of the European Union to the Location of R\&D Multinational Firms?

Iulia Siedschlag, Donal Smith, Camelia Turcu, Xiaoheng Zhang

Do Foreign Mergers and Acquisitions Boost Firm Productivity?

Marc Schiffbauer, Iulia Siedschlag, Frances Ruane

Inclusion or Diversion in Higher Education in the Republic of I reland?

Delma Byrne

Welfare Regime and Social Class Variation in Poverty and Economic Vulnerability in Europe: An Analysis of EU-SILC

Christopher T. Whelan and Bertrand Maitre

Understanding the Socio-Economic Distribution and Consequences of Patterns of Multiple Deprivation:

An Application of Self-Organising Maps Christopher T. Whelan, Mario Lucchini, Maurizio Pisati and Bertrand Maître 
Explaining Structural Change in Cardiovascular Mortality in Ireland 1995-2005: A Time Series Analysis Richard Layte, Sinead O'Hara and Kathleen Bennett

EU Climate Change Policy 2013-2020: Using the Clean Development Mechanism More Effectively Paul K Gorecki, Seán Lyons and Richard S.J. Tol

Irish Public Capital Spending in a Recession Edgar Morgenroth

Exporting and Ownership Contributions to Irish Manufacturing Productivity Growth Anne Marie Gleeson, Frances Ruane

Eligibility for Free Primary Care and Avoidable Hospitalisations in Ireland Anne Nolan

Managing Household Waste in Ireland:

Behavioural Parameters and Policy Options John Curtis, Seán Lyons and Abigail O'CallaghanPlatt

Labour Market Mismatch Among UK Graduates; An Analysis Using REFLEX Data Seamus McGuinness and Peter J. Sloane

Towards Regional Environmental Accounts for Ireland

Richard S.J. Tol , Nicola Commins, Niamh Crilly, Sean Lyons and Edgar Morgenroth

EU Climate Change Policy 2013-2020: Thoughts on Property Rights and Market Choices

Paul K. Gorecki, Sean Lyons and Richard S.J. Tol

Measuring House Price Change David Duffy 
Richard S.J. Tol

The Determinants and Effects of Training at Work:

Bringing the Workplace Back In

Philip J. O'Connell and Delma Byrne

288

Climate Feedbacks on the Terrestrial Biosphere and the Economics of Climate Policy: An

Application of FUND

Richard S.J. Tol

The Behaviour of the I rish Economy: Insights from the HERMES macro-economic model Adele Bergin, Thomas Conefrey, John FitzGerald and Ide Kearney

Mapping Patterns of Multiple Deprivation Using Self-Organising Maps: An Application to EU-SILC Data for I reland Maurizio Pisati, Christopher T. Whelan, Mario Lucchini and Bertrand Maître

The Feasibility of Low Concentration Targets: An Application of FUND Richard S.J. Tol

Policy Options to Reduce I reland's GHG Emissions Instrument choice: the pros and cons of alternative policy instruments Thomas Legge and Sue Scott

Accounting for Taste: An Examination of Socioeconomic Gradients in Attendance at Arts Events Pete Lunn and Elish Kelly

The Economic Impact of Ocean Acidification on Coral Reefs

Luke M. Brander, Katrin Rehdanz, Richard S.J. Tol, and Pieter J.H. van Beukering

Assessing the impact of biodiversity on tourism flows: A model for tourist behaviour and its policy implications

Giulia Macagno, Maria Loureiro, Paulo A.L.D. Nunes and Richard S.J. Tol 
Advertising to boost energy efficiency: the Power of One campaign and natural gas consumption Seán Diffney, Seán Lyons and Laura Malaguzzi Valeri

International Transmission of Business Cycles Between I reland and its Trading Partners Jean Goggin and Iulia Siedschlag

Optimal Global Dynamic Carbon Taxation David Anthoff

Energy Use and Appliance Ownership in I reland Eimear Leahy and Seán Lyons

Discounting for Climate Change

David Anthoff, Richard S.J. Tol and Gary W. Yohe

Projecting the Future Numbers of Migrant Workers in the Health and Social Care Sectors in Ireland

Alan Barrett and Anna Rust

Economic Costs of Extratropical Storms under Climate Change: An application of FUND Daiju Narita, Richard S.J. Tol, David Anthoff

The Macro-Economic Impact of Changing the Rate of Corporation Tax

Thomas Conefrey and John D. Fitz Gerald

The Games We Used to Play An Application of Survival Analysis to the Sporting Life-course Pete Lunn

Exploring the Economic Geography of I reland Edgar Morgenroth

Benchmarking, Social Partnership and Higher Remuneration: Wage Settling Institutions and the Public-Private Sector Wage Gap in I reland Elish Kelly, Seamus McGuinness, Philip O'Connell

A Dynamic Analysis of Household Car Ownership in I reland 
Anne Nolan

The Determinants of Mode of Transport to Work in the Greater Dublin Area

Nicola Commins and Anne Nolan

Resonances from Economic Development for Current Economic Policymaking Frances Ruane

The Impact of Wage Bargaining Regime on FirmLevel Competitiveness and Wage Inequality: The Case of I reland

Seamus McGuinness, Elish Kelly and Philip O'Connell

Poverty in Ireland in Comparative European Perspective

Christopher T. Whelan and Bertrand Maître

A Hedonic Analysis of the Value of Rail Transport in the Greater Dublin Area Karen Mayor, Seán Lyons, David Duffy and Richard S.J. Tol

Comparing Poverty Indicators in an Enlarged EU Christopher T. Whelan and Bertrand Maître

Fuel Poverty in Ireland: Extent, Affected Groups and Policy Issues Sue Scott, Seán Lyons, Claire Keane, Donal McCarthy and Richard S.J. Tol

The Misperception of Inflation by Irish Consumers David Duffy and Pete Lunn

The Direct Impact of Climate Change on Regional Labour Productivity

Tord Kjellstrom, R Sari Kovats, Simon J. Lloyd, Tom Holt, Richard S.J. Tol

Damage Costs of Climate Change through Intensification of Tropical Cyclone Activities: An Application of FUND Daiju Narita, Richard S. J. Toland David Anthoff Are Over-educated People Insiders or Outsiders? 
A Case of J ob Search Methods and Overeducation in UK

Aleksander Kucel, Delma Byrne

Metrics for Aggregating the Climate Effect of Different Emissions: A Unifying Framework Richard S.J. Tol, Terje K. Berntsen, Brian C. O'Neill, J an S. Fuglestvedt, Keith P. Shine, Yves Balkanski and Laszlo Makra

Intra-Union Flexibility of Non-ETS Emission Reduction Obligations in the European Union Richard S.J. Tol

The Economic Impact of Climate Change Richard S.J. Tol

Measuring International Inequity Aversion Richard S.J. Tol

Using a Census to Assess the Reliability of a National Household Survey for Migration Research: The Case of I reland Alan Barrett and Elish Kelly

Risk Aversion, Time Preference, and the Social Cost of Carbon

David Anthoff, Richard S.J. Tol and Gary W. Yohe

The Impact of a Carbon Tax on Economic Growth and Carbon Dioxide Emissions in I reland Thomas Conefrey, John D. Fitz Gerald, Laura Malaguzzi Valeri and Richard S.J. Tol

The Distributional Implications of a Carbon Tax in Ireland

Tim Callan, Sean Lyons, Susan Scott, Richard S.J. Tol and Stefano Verde

Measuring Material Deprivation in the Enlarged EU

Christopher T. Whelan, Brian Nolan and Bertrand Maitre

Marginal Abatement Costs on Carbon-Dioxide Emissions: A Meta-Analysis Onno Kuik, Luke Brander and Richard S.J. Tol 
Incorporating GHG Emission Costs in the Economic Appraisal of Projects Supported by State Development Agencies Richard S.J. Tol and Seán Lyons

A Carton Tax for I reland Richard S.J. Tol, Tim Callan, Thomas Conefrey, John D. Fitz Gerald, Seán Lyons, Laura Malaguzzi Valeri and Susan Scott

Non-cash Benefits and the Distribution of Economic Welfare

Tim Callan and Claire Keane

Scenarios of Carbon Dioxide Emissions from Aviation Karen Mayor and Richard S.J. Tol

The Effect of the Euro on Export Patterns: Empirical Evidence from Industry Data Gavin Murphy and Iulia Siedschlag

The Economic Returns to Field of Study and Competencies Among Higher Education Graduates in Ireland Elish Kelly, Philip O'Connell and Emer Smyth

European Climate Policy and Aviation Emissions Karen Mayor and Richard S.J. Tol

Aviation and the Environment in the Context of the EU-US Open Skies Agreement Karen Mayor and Richard S.J. Tol

Yuppie Kvetch? Work-life Conflict and Social Class in Western Europe Frances McGinnity and Emma Calvert

Immigrants and Welfare Programmes: Exploring the Interactions between Immigrant Characteristics, Immigrant Welfare Dependence and Welfare Policy

Alan Barrett and Yvonne McCarthy

How Local is Hospital Treatment? An Exploratory Analysis of Public/Private Variation in Location of Treatment in Irish Acute Public Hospitals Jacqueline O'Reilly and Miriam M. Wiley 
The I mmigrant Earnings Disadvantage Across the Earnings and Skills Distributions: The Case of Immigrants from the EU's New Member States in Ireland

Alan Barrett, Seamus McGuinness and Martin O'Brien

Europeanisation of Inequality and European Reference Groups Christopher T. Whelan and Bertrand Maitre

Managing Capital Flows: Experiences from Central and Eastern Europe J ürgen von Hagen and Iulia Siedschlag

ICT Diffusion, Innovation Systems, Globalisation and Regional Economic Dynamics: Theory and Empirical Evidence Charlie Karlsson, Gunther Maier, Michaela Trippl, Iulia Siedschlag, Robert Owen and Gavin Murphy

Welfare and Competition Effects of Electricity Interconnection between Great Britain and Ireland Laura Malaguzzi Valeri

Is FDI into China Crowding Out the FDI into the European Union?

Laura Resmini and Iulia Siedschlag

Estimating the Economic Cost of Disability in Ireland

J ohn Cullinan, Brenda Gannon and Seán Lyons

229 Controlling the Cost of Controlling the Climate: The I rish Government's Climate Change Strategy Colm McCarthy, Sue Scott

228 The Impact of Climate Change on the BalancedGrowth-Equivalent: An Application of FUND David Anthoff, Richard S.J. Tol

Changing Returns to Education During a Boom? The Case of I reland Seamus McGuinness, Frances McGinnity, Philip O'Connell 
'New' and 'Old' Social Risks: Life Cycle and Social Class Perspectives on Social Exclusion in I reland Christopher T. Whelan and Bertrand Maître

The Climate Preferences of I rish Tourists by Purpose of Travel

Seán Lyons, Karen Mayor and Richard S.J. Tol

A Hirsch Measure for the Quality of Research Supervision, and an Illustration with Trade Economists

Frances P. Ruane and Richard S.J. Tol

Environmental Accounts for the Republic of Ireland: 1990-2005

Seán Lyons, Karen Mayor and Richard S.J. Tol

Assessing Vulnerability of Selected Sectors under Environmental Tax Reform: The issue of pricing power

J. Fitz Gerald, M. Keeney and S. Scott

Climate Policy Versus Development Aid Richard S.J. Tol

Exports and Productivity - Comparable Evidence for 14 Countries

The International Study Group on Exports and Productivity

Energy-Using Appliances and Energy-Saving Features: Determinants of Ownership in I reland J oe O'Doherty, Seán Lyons and Richard S.J. Tol

The Public/Private Mix in Irish Acute Public Hospitals: Trends and Implications Jacqueline O'Reilly and Miriam M. Wiley

Regret About the Timing of First Sexual Intercourse: The Role of Age and Context Richard Layte, Hannah McGee

Determinants of Water Connection Type and Ownership of Water-Using Appliances in I reland J oe O'Doherty, Seán Lyons and Richard S.J. Tol 
Emer Smyth

214

The Value of Lost Load

Richard S.J. Tol

213

Adolescents' Educational Attainment and School Experiences in Contemporary I reland

Merike Darmody, Selina McCoy, Emer Smyth

Acting Up or Opting Out? Truancy in Irish Secondary Schools

Merike Darmody, Emer Smyth and Selina McCoy

Where do MNEs Expand Production: Location Choices of the Pharmaceutical Industry in Europe after 1992

Frances $P$. Ruane, Xiaoheng Zhang

Holiday Destinations: Understanding the Travel Choices of Irish Tourists

Seán Lyons, Karen Mayor and Richard S.J. Tol

The Effectiveness of Competition Policy and the Price-Cost Margin: Evidence from Panel Data Patrick McCloughan, Seán Lyons and William Batt

Tax Structure and Female Labour Market

Participation: Evidence from I reland

Tim Callan, A. Van Soest, J.R. Walsh 